Victor V. Carneiro de Albuquerque ${ }^{1}$

\title{
COMÉRCIO DE PRODUTOS BIOTECNOLÓGICOS NO BRASIL: UMA PROPOSTA DE INTERPRETAÇÃO CONSTITUCIONAL COM BASE NA DIGNIDADE DA PESSOA HUMANA E NO DIREITO FUNDAMENTAL À SAÚDE
}

Commerce of biotech products in Brazil: constitutional reasoning based on human dignity and on the fundamental right to health

${ }^{1}$ UniCEUB. Brasília/DF, Brasil.

Correspondência: Victor V. Carneiro de Albuquerque. E-mail: victor.albuquerque@ gmail.com.

Recebido em: 19/02/2015. Revisado em: 14/04/2015. Aprovado em: 11/05/2015. 


\section{RESUMO}

A indústria farmacêutica investe no desenvolvimento de produtos baseados em substâncias humanas, sobretudo os obtidos por meio de manipulação celular e genética. Nada obstante, o marco legal brasileiro ainda se funda no paradigma de drogas sintéticas e, portanto, é pouco adaptado para regular novos produtos biotecnológicos em desenvolvimento. O presente artigo examina um dispositivo constitucional que traz norma sobre o comércio de substâncias humanas, com o objetivo de promover interpretação que melhor atenda ao princípio da dignidade da pessoa humana e promova o direito fundamental à saúde.

\section{Palavras-Chave}

Biotecnologia; Dignidade da Pessoa Humana; Direito à Saúde; Direitos Fundamentais.

\section{ABSTRACT}

The recent trend of pharmaceutical industry is to develop products based on human tissues, especially by using cellular and genetic manipulation. Current Brazilian regulation is however still largely concerned with traditional synthetic drugs. This article examines one particular constitutional rule on the commercialization of human substances to assure the protection of human dignity and on the promotion of the fundamental right to health recognized by the Brazilian Constitution.

\section{Keywords}

Biotechnology; Human Dignity; Human Rights; Right to Health. 


\section{Introdução}

A indústria farmacêutica tem alterado seu paradigma nos últimos 20 anos, período em que seu foco migrou do desenvolvimento de princípios terapêuticos sintéticos para produtos biológicos e técnicas sofisticadas de manipulação biológica ${ }^{1}$.

O marco inicial da mudança é remotamente identificado nas pesquisas posteriores à descoberta da estrutura do ácido desoxirribonucleico (ADN, ou DNA em sua sigla inglesa, mais usual), nas décadas de 1960 e 1970. A mudança tomou impulso na segunda metade da década de 1990, com o domínio de técnicas de clonagem animal e o mapeamento do genoma humano.

Os termos "biotecnologia" e "produtos biotecnológicos" possuem várias alternativas de conceituação, variáveis segundo o referencial histórico adotado por seu propositor. Neste trabalho, entende-se biotecnologia como "atividade baseada em conhecimentos multidisciplinares, que utiliza agentes biológicos para fazer produtos úteis ou resolver problemas" ${ }^{\prime 2}$. Interessa aqui especialmente seu uso para a oferta de "produtos úteis" para a "solução de problemas" relacionados à saúde humana. Por derivação, produto biotecnológico será considerado o resultado da aplicação da biotecnologia para atender a uma necessidade terapêutica humana, principalmente por meio de técnicas de manipulação de células e tecidos humanos.

A evolução da técnica não foi acompanhada pela modificação do marco normativo brasileiro sobre a indústria farmacêutica, estando este ainda substancialmente fincado no paradigma dos insumos sintéticos ${ }^{3}$.

Em verdade, as leis voltadas às substâncias terapêuticas no país não trazem disposições detalhadas sobre produtos biotecnológicos, tratando-os de forma quase indistinta dos obtidos com base na tecnologia tradicional.

Ao final da década de 1990, a criação da Agência Nacional de Vigilância Sanitária (Anvisa), por meio da Lei n. 9.782/19994, procurou dar ao setor farmacêutico um ente regulador destacado do órgão central do planejamento da saúde

\footnotetext{
${ }^{1}$ MOSER, Antônio. Biotecnologia e bioética: para onde vamos? Petrópolis: Vozes, 2004. p. 139.

${ }^{2}$ MARLAJOVICH, Maria. Biotecnologia. Rio de Janeiro: Axcel, 2004. p. 4.

${ }^{3}$ Ver BRASIL. Lei Federal n. 5.991, de 17 de dezembro de 1973. Dispõe sobre o Controle Sanitário do Comércio de Drogas, Medicamentos, Insumos Farmacêuticos e Correlatos, e dá outras Providências. Disponível em: <http://www.planalto.gov.br/ccivil_03/leis/L5991.htm>. Acesso em: 29 jan. 2016. Ver também BRASIL. Lei Federal n. 6.360, de 23 de setembro de 1976. Dispõe sobre a Vigilância Sanitária a que ficam sujeitos os Medicamentos, as Drogas, os Insumos Farmacêuticos e Correlatos, Cosméticos, Saneantes e Outros Produtos, e dá outras Providências. Disponível em: <http://www.planalto.gov.br/ccivil_03/Leis/ L6360.htm>. Acesso em: 29 jan. 2016.

${ }^{4}$ BRASIL. Lei Federal n. 9.782, de 26 de janeiro de 1999. Define o Sistema Nacional de Vigilância Sanitária, cria a Agência Nacional de Vigilância Sanitária, e dá outras providências. Disponível em: <http://www.planalto.gov.br/ccivil_03/leis/L9782.htm>. Acesso em: 29 jan. 2016.
} 
no país, também com o objetivo de permitir um acompanhamento mais célere das mudanças técnicas do setor.

Dado seu caráter geral, contudo, a Lei n. 9.782/1999 fez apenas duas menções a produtos biológicos 5 . Em ambos os casos, tratou de especificar sua competência normativa infralegal, primeiro sobre imunobiológicos, segundo sobre produtos obtidos por meio de engenharia genética (artigo $8^{\circ}$, parágrafo $1^{\circ}$, incisos VII e XI, respectivamente).

Há, porém, um dispositivo constitucional de impacto decisivo para o desenvolvimento do setor brasileiro de biotecnologia. Trata-se do artigo 199, parágrafo $4^{\circ}$, da Constituição Federal de 1988 (CF/88):

Art. 199. A assistência à saúde é livre à iniciativa privada.

$[\ldots]$

$\$ 4^{\circ}$ - A lei disporá sobre as condições e os requisitos que facilitem a remoção de órgãos, tecidos e substâncias humanas para fins de transplante, pesquisa e tratamento, bem como a coleta, processamento e transfusão de sangue e seus derivados, sendo vedado todo tipo de comercializaçãó ${ }^{6}$.

Em que pese a complexidade do texto transcrito, parece possível afirmar que este aparentemente traz uma regra contra toda e qualquer comercialização de certa categoria de produtos. A identificação precisa do alvo da vedação constitucional é, contudo, questão polêmica e rica de consequências jurídicas para o desenvolvimento da indústria biotecnológica no Brasil.

De fato, uma interpretação inicial pode ser a de que o comércio de órgãos, tecidos, substâncias humanas e sangue em si é proibido, além da comercialização de quaisquer produtos destes derivados ou que os contenham em alguma medida.

Tal entendimento foi adotado CF/88 Federal. Citam-se, por oportuno, Celso Ribeiro Bastos e Ives Gandra Martins, que, em obra conjunta, assim comentaram o parágrafo $4^{\circ}$ do artigo 199 da Constituição:

$\mathrm{O} \$ 4^{\circ}$ do art. 199, segundo o deputado Roberto Campos, introduziu no país a "sanguebrás". Proibindo qualquer tipo de comercialização sobre a remoção de órgãos, tecidos e substâncias humanas para fins de transplante e tratamento, assim como o processamento e a transformação de seus sangues e derivados, determinou o constituinte que a lei estabelecesse as condições e requisitos para facilitar

\footnotetext{
${ }^{5} \mathrm{~A}$ lei não usa os termos "biotecnologia" ou "produto biotecnológico", mas trabalha com seus conceitos de forma assistemática.

${ }^{6}$ BRASIL. Constituição da República Federativa do Brasil de 1988. Disponível em: <http://www.planalto.gov. br/ccivil_03/constituicao/ConstituicaoCompilado.htm>. Acesso em: 29 jan. 2017.
} 
a sua ocorrência, dentro desses parâmetros. [...] O texto, todavia, é absolutista, pois ao dizer que é vedado qualquer tipo de comercialização, nitidamente proibiu até que os medicamentos feitos à base de sangue pudessem ser comercializados, o que vale dizer, o constituinte proibiu qualquer tipo de comercialização de qualquer tipo de medicamento que derivasse direta ou indiretamente de substâncias humanas, inclusive as autovacinas ${ }^{7}$.

Idêntica foi a opinião externada de Manoel Gonçalves Ferreira Filho, no sentido de que o dispositivo constitucional vedaria o comércio de substâncias humanas em qualquer estágio ${ }^{8}$ : "O ponto-chave deste texto é a proibição da comercialização de órgãos, tecidos e substâncias humanas, bem como do sangue e seus derivados. E isto para qualquer fim ou qualquer passo do processo de obtenção ou fornecimento".

A interpretação restritiva dos autores citados foi adotada pela Anvisa, após manifestação pontual de sua Procuradoria Federal quanto a pedido de registro de produto elaborado a partir de tecido ósseo obtido de cadáveres humanos ${ }^{9}$.

A posição restritiva à comercialização de produtos contendo substâncias humanas parece ter produzido eco na produção legislativa complementar ao artigo 199, parágrafo $4^{\circ}$, da CF/88. De fato, tanto a Lei n. 10.205/2001 (regula o ciclo do sangue, seus componentes e derivados), quanto a Lei n. 11.105/2005 ("lei de biossegurança") vedam expressamente a comercialização de sangue, seus derivados e componentes ${ }^{10}$, bem como a de células-tronco embrionárias utilizadas para fins de pesquisa e terapia ${ }^{11}$.

${ }^{7}$ BASTOS, Celso Ribeiro; MARTINS, Ives Gandra. Comentários à Constituição do Brasil. São Paulo: Saraiva, 2000. v. 8, p. 183. BASTOS, Celso Ribeiro; MARTINS, Ives Gandra. Comentários à Constituição do Brasil. São Paulo: Saraiva, 2000. v. 8, p. 183.

${ }^{8}$ FERREIRA FILHO, Manoel Gonçalves. Comentários à Constituição brasileira de 1988. 2. ed. São Paulo: Saraiva, 1999. p. 228.

9Parecer 209/02 - PROCR/ANVISA, aprovado em 21 de outubro de 2002.

${ }^{10} \mathrm{Art.} 1^{\circ}$ Esta Lei dispõe sobre a captação, proteção ao doador e ao receptor, coleta, processamento, estocagem, distribuição e transfusão do sangue, de seus componentes e derivados, vedada a compra, venda ou qualquer outro tipo de comercialização do sangue, componentes e hemoderivados, em todo o território nacional, seja por pessoas físicas ou jurídicas, em caráter eventual ou permanente, que estejam em desacordo com o ordenamento institucional estabelecido nesta Lei. BRASIL. Lei Federal n. 10.205, de 21 de março de 2001. Regulamenta o $\S 4^{\circ}$ do art. 199 da Constituição Federal, relativo à coleta, processamento, estocagem, distribuição e aplicação do sangue, seus componentes e derivados, estabelece o ordenamento institucional indispensável à execução adequada dessas atividades, e dá outras providências. Disponível em: <http://www.planalto.gov.br/ccivil_03/leis/leis_2001/l10205.htm>. Acesso em: 29 jan. 2016.

${ }^{11} \mathrm{Art.} 5^{\circ} \S 3^{\circ} \mathrm{E}$ vedada a comercialização do material biológico a que se refere este artigo e sua prática implica o crime tipificado no art. 15 da Lei no 9.434, de 4 de fevereiro de 1997. BRASIL. Lei Federal n. 10.205, de 21 de março de 2001. Regulamenta os incisos II, IV e V do $\S 1^{\circ}$ do art. 225 da Constituição Federal, estabelece normas de segurança e mecanismos de fiscalização de atividades que envolvam organismos geneticamente modificados - OGM e seus derivados, cria o Conselho Nacional de Biossegurança - CNBS, reestrutura a Comissão Técnica Nacional de Biossegurança - CTNBio, dispõe sobre a Política Nacional de Biossegurança - PNB, revoga a Lei n 8.974, de 5 de janeiro de 1995, e a Medida Provisória $n^{\circ} 2.191-9$, de 23 de agosto de 2001 , e os arts. $5^{\circ}, 6^{\circ}, 7^{\circ}, 8^{\circ}, 9^{\circ}, 10$ e 16 da Lei $n^{\circ} 10.814$, de 15 de dezembro de 2003 , e dá outras providências. Disponível em: <http://www.planalto.gov.br/ccivil_03/_ato2004-2006/2005/lei/ I11105.htm>. Acesso em: 29 jan. 2016. 
Ocorre que o prevalecimento do veto à comercialização de produtos que contenham substâncias humanas implica séria limitação ao desenvolvimento de produtos biotecnológicos terapêuticos no mercado nacional e, por conseguinte, redução de alternativas de ações para o combate e prevenção de doenças no país.

Tal como já dito, o atual paradigma da indústria farmacêutica é precisamente o uso de tecidos, células ou mesmo genes humanos para a fabricação de produtos terapêuticos biológicos, destinados a uso tanto no próprio indivíduo do qual foram retirados (uso autólogo) como em outrem (uso heterólogo). Assim, vedar o comércio de produtos com ou advindos de substâncias humanas equivale a suprimir o desenvolvimento de produtos tecnológicos por agentes privados.

De fato, em um sistema de mercado, a pesquisa e o desenvolvimento de produtos terapêuticos se dão não só por motivos altruísticos, mas primordialmente pelo intuito de lucrar com a sua oferta aos consumidores. Nesse sentido, proibir a comercialização de medicamentos desenvolvidos a partir de substâncias humanas afastaria o esforço privado desse setor da assistência à saúde, reservando ao poder público o ônus de introduzir soluções biotecnológicas para os problemas de saúde no Brasil.

Mesmo que se escolha não discutir a constitucionalidade do estabelecimento de um monopólio estatal em segmento da assistência à saúde, a interpretação do $\$ 4^{\circ}$ do artigo 199 da CF/88 não pode ser feita sem atentar para a qualificação da saúde como direito fundamental na ordem constitucional brasileira, bem como para os impactos do princípio constitucional da dignidade da pessoa humana na apreciação do caso.

Em verdade, 0 artigo $6^{\circ}$ da atual Constituição estabeleceu o direito à saúde como direito fundamental de natureza social, havendo a mesma Carta especificado, em seu artigo 196, tratar-se de "direito de todos" e de "dever do Estado".

Reconhecer a saúde como direito fundamental traz consequências relevantes para o Estado brasileiro. De um lado, implica limitar sua atuação em políticas que possam reduzir a oferta de soluções terapêuticas para os destinatários da norma concessiva do direito. De outro - e tendo em conta que o artigo 196 identifica satisfatoriamente o titular, o destinatário e o objeto do direito fundamental à saúde, reconhecido no artigo $6^{\circ} \mathrm{da} \mathrm{CF} / 88$-, deve ser reconhecido também um dever estatal no sentido de adotar políticas capazes de aumentar a oferta de alternativas para a proteção e promoção da saúde dos brasileiros.

De igual sorte, a proclamação pelo artigo $1^{\circ}$, inciso III, da CF/88 da dignidade da pessoa humana como princípio fundamental do Estado brasileiro irradia efeitos por todo o texto constitucional, servindo tanto de fundamento material para 
regras veiculadas em dispositivos constitucionais quanto como parâmetro interpretativo para normas veiculadas pelo texto da Constituição ${ }^{12}$.

Nesse diapasão, já é possível antecipar que a interpretação restritiva quanto ao alcance do parágrafo $4^{\circ}$ do artigo 199 do texto constitucional, conquanto possível, não está isenta de questionamentos sobre sua adequação à ordem constitucional.

Põe-se, desse modo, a questão de examinar a amplitude normativa do parágrafo $4^{\circ}$ do artigo 199 da CF/88 e, de forma mais específica, se o seu reconhecimento como norma proibidora do comércio de produtos contendo substância humana se coaduna com hermenêutica constitucional pautada na efetivação dos direitos fundamentais.

A discussão feita no presente trabalho tem por premissa a teoria geral dos direitos fundamentais, construída com base na jurisprudência do Tribunal Constitucional Federal alemão (TCF), proposta de forma sintética por Robert Alexy. A escolha de tal marco teórico tem caráter pragmático.

De fato, o estudo da jurisprudência do TCF e da doutrina nela baseada tem gozado de ampla divulgação por professores brasileiros, sobretudo aqueles com publicações em hermenêutica constitucional a partir da década de 1990. De igual sorte, o Supremo Tribunal Federal (STF) brasileiro regularmente cita (e, por vezes, expressamente utiliza como referência) precedentes do TCF e a doutrina a partir destes elaborada.

No caso da matéria discutida, atenta-se para o fato de que a Lei Fundamental da República Federal da Alemanha de 1949 traz, em seu artigo 1º, 1, o princípio da inviolabilidade da dignidade da pessoa humana em dispositivo similar ao artigo $1^{\circ}$, inciso III, da CF $/ 88^{13}$.

Uma primeira premissa a ser utilizada neste artigo é a de que tanto o parágrafo $4^{\circ}$ do artigo 199 quanto os artigos $1^{\circ}$, inciso III, 6º e 196, todos da CF/88, veiculam normas de direitos fundamentais.

Adicionalmente, tem-se também como premissa que a interpretação da regra do artigo 199, parágrafo $4^{\circ}$, no sentido de proibir toda comercialização de produtos derivados de células, tecidos ou substâncias humanas (biotecnológicos, em uma síntese não perfeita, porém funcional) conflita com o direito à saúde garantido pelos artigos $6^{\circ}$ e 196 da $\mathrm{CF} / 88$, bem como pode se mostrar contrária à interpretação específica do alcance do princípio da dignidade da pessoa humana trazido pelo artigo $1^{\circ}$, inciso III, da Constituição.

${ }^{12}$ Sobre a dignidade da pessoa humana como parâmetro interpretativo da Constituição, ver SARLET, Ingo Wolfgang. Dignidade da pessoa humana e direitos fundamentais na Constituição Federal de1988. 9. ed. Porto Alegre: Livr. do Advogado, 2011. p. 95.

${ }^{13}$ Eis a redação do artigo $1^{\circ}, 1$, da Lei Fundamental Alemã: “(1) A dignidade da pessoa humana é intangível. Respeitá-la e protegê-la é obrigação de todo o poder público”. (Tradução do autor) 
Portanto, reconhecido o potencial conflito entre normas de direitos fundamentais, pretende-se apontar solução por meio do mecanismo da ponderação, intermediada pela regra da proporcionalidade. Em resumo do que se verá a seguir, compreende-se que a estrutura utilizada pelo artigo $196 \mathrm{da} C \mathrm{CF} / 88$ para densificar o direito à saúde trazido originalmente pelo artigo $6^{\circ}$ da Constituição veda postura estatal que, de forma não razoável, limite o número de soluções terapêuticas ofertadas ao público.

De igual sorte, tem-se que a vedação trazida pelo parágrafo $4^{\circ}$ do artigo 199 funda-se no princípio da dignidade da pessoa humana - que, por sua natureza, pode ser atendido por mais de uma maneira e mesmo parcialmente, segundo as possibilidades fáticas e jurídicas do caso concreto. Pretende-se demonstrar, nesse sentido, que as peculiaridades do caso em apreço não demandam a vedação adotada pelo atual entendimento da autoridade sanitária federal quanto ao comércio de produtos biotecnológicos para uso humano.

Delineadas, assim, as premissas gerais do trabalho, passemos à discussão das hipóteses.

\section{O parágrafo $4^{\circ}$ do artigo 199 da $\mathrm{CF} / 88$ como norma de proteção da dignidade do doador de órgãos e tecidos}

A leitura do parágrafo $4^{\circ}$ do artigo 199 da Constituição permite identificar três comandos normativos distintos. Os dois primeiros são direcionados para que o Congresso Nacional crie, por meio de lei, condições e requisitos destinados a facilitar a remoção de órgãos, tecidos e substâncias humanas para fins de transplante, pesquisa e tratamento, bem como regule a coleta, o processamento e a transfusão de sangue humano e seus derivados, respectivamente.

Um terceiro preceito normativo é direcionado a todos indistintamente e traz limitação material ao conteúdo das leis exigidas pela parte inicial do dispositivo constitucional: trata-se da vedação ao comércio das substâncias de origem humana ${ }^{14}$ coletadas.

Assim dissecado o dispositivo, parece lícito ressaltar que todas as suas partes revelam a intenção de dar concretude ao princípio da dignidade da pessoa humana, consagrado pelo artigo $1^{\circ}$, inciso III, da $\mathrm{CF} / 88$.

De fato, facilitar a coleta de substâncias de origem humana para fins terapêuticos e de pesquisa visa tanto a agilizar o uso de técnicas e produtos já conhecidos (como transfusões sanguíneas e transplante de órgãos) quanto a adicionar ao arsenal terapêutico novas opções, estas desenvolvidas por pesquisa científica (caso

\footnotetext{
${ }^{14}$ Usa-se "substâncias de origem humana" para abarcar todas as espécies mencionadas pelo parágrafo $4^{\circ}$ do artigo 199.
} 
das terapias celulares, gênicas e, enfim, da biotecnologia como gênero). Trata-se de estimular meios para a promoção da saúde do indivíduo e, por conseguinte, assegurar a dignidade de sua vida.

Assim, oportuno citar que, em voto condutor proferido no julgamento da Ação Direta de Inconstitucionalidade 3510/DF, o relator identificou no parágrafo $4^{\circ}$ do artigo 199 norma de inspiração solidária, destinada à promoção da saúde no país ${ }^{15}$ :

55. Providencial a regra constitucional, essa, que, sob inspiração nitidamente fraternal ou solidária, transfere para a lei ordinária a possibilidade de sair em socorro daquilo que mais importa para cada indivíduo: a preservação de sua própria saúde, primeira das condições de qualificação e continuidade de sua vida. (destaques no original)

De igual sorte, a vedação ao comércio de substâncias de origem humana a serem coletadas para fins de transplante, transfusão ou pesquisa traduz regra cujo fundamento material se encontra no princípio da dignidade da pessoa humana ${ }^{16}$. Tanto a persistente desigualdade social brasileira quanto o histórico específico do país nesta seara serviram para que o constituinte se acautelasse contra o risco da reificação do ser humano, sobretudo do mais pobre, que poderia ser levado por suas necessidades a mercadejar seu próprio corpo como fonte de renda.

Trata-se, aliás, da conclusão a que chegaram Celso Ribeiro Bastos e Ives Gandra Martins ao comentar o dispositivo constitucional em questão: "Nitidamente, o dispositivo objetivou evitar o comércio ilegal de órgãos e sangue, assim como a possível exploração de pessoas sem recursos, que as pudesse levar a disporem de seus órgãos mediante negociação" ${ }^{17}$.

Vê-se, portanto, que o mesmo princípio constitucional ("dignidade da pessoa humana") serve como suporte material para dois comandos normativos do parágrafo $4^{\circ}$ do artigo 199: um no sentido de criação de competência normativa infraconstitucional com um conteúdo pré-fixado (criação de leis que facilitem a remoção de substâncias de origem humana para fins terapêuticos e de pesquisa) e outro, na forma de regra, que proíbe a comercialização na coleta de tais substâncias.

Porém, ocorre que, se não há dúvida quanto às normas de competência para a criação de leis, a regra de vedação do comércio pode se mostrar avessa ao próprio princípio que a exige.

\footnotetext{
${ }^{15}$ BRASIL. SUPREMO TRIBUNAL FEDERAL. Ação Direta de Inconstitucionalidade 3.510/DF. Disponível em: <http://www.stf.jus.br/portal/processo/verProcessoAndamento.asp?incidente=2299631>. Acesso em: 29 jan. 2016.

${ }^{16}$ Sobre o papel dos princípios de direitos fundamentais como fundamentos materiais para regras, ver ALEXY, Robert. Teoria dos direitos fundamentais. 2. ed. São Paulo: Malheiros Ed., 2014. p. 90-91.

${ }^{17}$ BASTOS, Celso Ribeiro; MARTINS, Ives Gandra. op. cit., p. 183.
} 
Tal como já dito, a extensão do veto ao comércio de produtos biotecnológicos implica sua oferta apenas pelo Estado brasileiro (único capaz de recompor os custos da pesquisa, desenvolvimento e fabricação dos produtos por mecanismos outros além do preço). Esta conclusão, por conseguinte, estabelece um monopólio público sobre importante setor da assistência à saúde (a fabricação de medicamentos com base na biotecnologia).

No entanto, o parágrafo $4^{\circ}$ refere-se ao artigo 199 da $\mathrm{CF} / 88$, no qual é garantida à iniciativa privada liberdade de atuação na assistência à saúde. Assim, a tese pelo monopólio torna-se, no mínimo, questionável.

Há, ademais, razões mais substanciais para afastar entendimento restritivo do comércio de produtos biotecnológicos com base numa leitura "absolutista"18 do parágrafo $4^{\circ}$ do artigo 199. Refere-se aqui às consequências normativas do reconhecimento da saúde como direito de todos e dever do Estado, derivado do artigo 196 da CF/88, bem como a uma interpretação mais expandida do princípio da dignidade da pessoa humana.

\section{O direito fundamental à saúde como dever do Estado e seus efeitos nas políticas de oferta de soluções terapêuticas}

$\mathrm{O}$ artigo $6^{\circ} \mathrm{da} \mathrm{CF} / 88$ lista direitos sociais dos brasileiros, encabeçados pelo direito à saúde. A localização do artigo no título referente aos direitos e garantias fundamentais evidencia a qualidade dos direitos sociais veiculados no capítulo, o que, por sua vez, traz consequências jurídico-constitucionais relevantes.

A primeira delas é sua aplicabilidade imediata, garantida pelo parágrafo $1^{\circ}$ do artigo $5^{\circ}$ da $\mathrm{CF} / 88$, que se refere não aos direitos e às garantias individuais (trazidos ao longo do artigo $5^{\circ}$ ), mas a todas as normas definidoras de direitos fundamentais. Assim, não cabem mais posições que concebam normas definidoras de direitos fundamentais ("qualquer direito fundamental") apenas como normas programáticas ou "normas matrizes de outras normas"19.

Mais relevante, entretanto, é o reconhecimento de duplo aspecto de posições jurídicas favoráveis ao titular do direito fundamental em questão. Por um lado, pode ele exigir a abstenção de condutas (do Estado ou de terceiros, materiais ou, quanto ao primeiro, também normativas) que violem ou ameacem seu direito. Em uma vertente positiva, ademais, o titular pode exigir prestações para garantir o direito constitucionalmente assegurado ${ }^{20,21}$.

\footnotetext{
${ }^{18}$ A expressão é de BASTOS, Celso Ribeiro; MARTINS, Ives Gandra. op. cit., p. 183.

${ }^{19}$ MENDES, Gilmar Ferreira; COELHO, Inocêncio Mártires; BRANCO, Paulo Gonet. Curso de direito constitucional. 2. ed. São Paulo: Saraiva, 2008. p. 251.

${ }^{20}$ SILVA, José Afonso da. Curso de direito constitucional positivo. 17. ed. São Paulo: Malheiros Ed., 1999. p. 312.

${ }^{21}$ Note-se que a Lei Fundamental alemã não consagrou direitos fundamentais prestacionais como a Constituição brasileira, razão pela qual parte da doutrina alemã não os entende constitucionalmente exigiveis. Ver HESSE, Konrad. Elementos de direito constitucional da República Federal da Alemanha. Porto Alegre: Sérgio Antônio Fabris, 1998. p. 170.
} 
No caso específico da $\mathrm{CF} / 88$, o direito à saúde - inicialmente proclamado no artigo $6^{\circ}$ - foi densificado pelo artigo 196, que descreveu uma relação triádica entre o titular do direito, seu destinatário e o essencial de seu objeto ou conteúdo.

Assim, a relação triádica compreende todos os brasileiros (titulares) e o Estado (destinatário principal), tendo como objeto a garantia de "políticas sociais e econômicas que visem à redução do risco da doença e de outros agravos [à saúde] e ao acesso universal e igualitário às ações e serviços para sua [da saúde] promoção, proteção e recuperação".

A efetividade do direito fundamental à saúde, em particular na sua vertente prestacional, foi há muito reconhecida pelo STF, como bem ressaltado no trecho de voto condutor no precedente de que se dá notícia:

O Poder Público, qualquer que seja a esfera institucional de sua atuação no plano da organização federativa brasileira, não pode mostrar-se indiferente ao problema da saúde da população, sob pena de incidir, ainda que por censurável omissão, em grave comportamento inconstitucional. A interpretação da norma programática não pode transformá-la em promessa constitucional inconsequente. O caráter programático da regra inscrita no art. 196 da Carta Política - que tem por destinatários todos os entes políticos que compõem, no plano institucional, a organização federativa do Estado brasileiro - não pode converter-se em promessa constitucional inconsequente, sob pena de o Poder Público, fraudando justas expectativas nele depositadas pela coletividade, substituir, de maneira ilegítima, o cumprimento de seu impostergável dever, por um gesto irresponsável de infidelidade governamental ao que determina a própria Lei Fundamental do Estado ${ }^{22}$.

Assim, o reconhecimento da natureza prestacional do direito à saúde ${ }^{23}$ e de sua caracterização como dever do Estado permite traçar conclusão parcial jurídico-interpretativa para o caso em comento: a necessidade de adoção de políticas públicas que visem ao acesso ampliado e universal a soluções terapêuticas.

Ocorre, contudo, que a extensão da regra proibitiva veiculada pelo parágrafo $4^{\circ}$ do artigo 199 da CF/88 também à comercialização de produtos biotecnológicos implica precisamente uma política de restrição ao acesso de ações para a "diminuição do risco de doença" ou para a "promoção, proteção e recuperação da saúde" nos moldes do artigo 196.

\footnotetext{
${ }^{22}$ BRASIL. SUPREMO TRIBUNAL FEDERAL. Segunda Turma. Agravo Regimental em Recurso Especial 271.286-8/RS. Julgamento: 12. Set. 2000. Publicado no Diário da Justiça de 24. Nov. 2000.

${ }^{23} \mathrm{Ou}$, ao menos, como um “direito a algo". Ver ALEXY, Robert. op. cit., p. 193.
} 
Identifica-se, dessa forma, tensão entre o mandado de otimização contido nas normas do direito fundamental à saúde como direito a políticas de acesso a soluções terapêuticas e a regra do parágrafo $4^{\circ}$ do artigo $199 \mathrm{da} \mathrm{CF} / 88$, ao menos como interpretada por parte da doutrina e pela autoridade sanitária nacional.

Tendo-se em conta que a regra do parágrafo $4^{\circ}$ se fundamenta, segundo aqui defendido, no princípio da dignidade da pessoa humana, a solução do conflito há de ser feita por meio de ponderação, nos moldes adotados no Brasil segundo a experiência alemã.

\section{A regra da proporcionalidade como método para a verificação da constitucionalidade do veto ao comércio de produtos biotecnológicos}

O método utilizado pelo STF para a solução de conflitos de normas de direitos fundamentais tem sido a ponderação, operacionalizada por meio da proporcionalidade, tal como corrente na jurisprudência do TCF e sistematizada pela doutrina alemã sobre a matéria ${ }^{24}$.

A ponderação se dá com o intuito de estabelecer, no caso concreto, uma relação de precedência condicionada entre as normas em conflito ${ }^{25}$, de maneira a identificar qual terá sua incidência privilegiada na relação jurídica sob exame.

Na discussão sobre a possibilidade de comercialização de produtos terapêuticos biotecnológicos, duas peculiaridades devem ser ressaltadas. A primeira diz respeito ao fato de que o conflito se dá entre uma vedação estabelecida sob a forma de regra (parágrafo $4^{\circ}$ do artigo 199, parte final) e outras normas estruturadas primordialmente como princípios (artigos $6^{\circ} \mathrm{e} 196$ ).

O marco teórico para o manejo de normas de direitos fundamentais usa a premissa de que estas possuem natureza dupla, tanto de regra como de princípios $^{26}$. Ademais, prega uma prevalência das normas veiculadas pela Constituição primordialmente na forma de regras. Veja-se, a propósito, trecho de Alexy sobre o ponto:

[...] tanto as regras estabelecidas pelas disposições constitucionais quanto os princípios também por elas estabelecidos são normas constitucionais. Isso traz à tona a questão da hierarquia entre os dois níveis. A resposta a essa pergunta somente pode

\footnotetext{
${ }^{24} \mathrm{Citam}$-se dois casos em que questões bioéticas advindas de normas de direitos fundamentais foram solucionadas pelo método mencionado. 0 primeiro foi a Ação Direta de Inconstitucionalidade 3510/DF. O segundo, a Arguição de Descumprimento de Preceito Fundamental 54/DF (com menção expressa a ponderação e proporcionalidade no voto do ministro relator). BRASIL. SUPREMO TRIBUNAL FEDERAL. ADPF 54. Disponivel em: <http://www.stf.jus.br/portal/processo/verProcessoAndamento.asp?incidente=2226954>. Acesso em: 29 jan. 2016.

${ }^{25}$ ALEXY, Robert. op. cit., p. 96.

${ }^{26}$ Id. Ibid., p. 139.
} 
sustentar que, do ponto de vista da vinculação à Constituição, há uma primazia do nível das regras. Ainda que o nível dos princípios também seja o resultado de um ato de positivação, ou seja, de uma decisão, a decisão a favor de princípios passíveis de entrar em colisão deixa muitas questões em aberto, pois um grupo de princípios pode acomodar as mais variadas decisões sobre relações de preferência e é, por isso, compatível com regras bastante distintas ${ }^{27}$.

É preciso, contudo, não antecipar respostas irrefletidas. Mesmo normas de direitos fundamentais veiculadas por meio de regras são passíveis de ponderação. É possível estabelecer, com base em norma de direito fundamental estruturada como princípio, cláusula de exclusão da regra a ser examinada no processo de ponderação ${ }^{28}$. Assim, a primazia das regras é relativa e pode ser afastada em caso concreto por meio de argumentação que demonstre a existência de razões constitucionais para tanto.

Eis, por oportuno, trecho da obra de Alexy acerca da questão:

Assim, embora a extensão e a força da vinculação “à lei” na argumentação no âmbito dos direitos fundamentais seja limitada, ela existe. Isso não contradiz a teoria dos princípios. Como já foi demonstrado, as normas de direito fundamentais têm um duplo caráter, como regras e princípios. Na medida em que o legislador constituinte tenha tomado decisões na forma de regras, elas são vinculantes, a não ser que seja possível introduzir razões constitucionais suficientes contra essa vinculação ${ }^{29}$.

Antes de apontarmos se, em nosso sentir, haveria razões para afastar a primazia da regra de vedação trazida pelo parágrafo $4^{\circ}$ do artigo 199 sobre comércio de produtos biotecnológicos, convém ressaltar a segunda peculiaridade do caso em discussão.

Trata-se da circunstância de as duas normas em conflito estarem fundamentadas no mesmo princípio de direito fundamental: o da dignidade da pessoa humana.

De fato, a vedação trazida pelo parágrafo $4^{\circ}$ do artigo 199 busca proteger indivíduos contra o risco de serem reduzidos à posição de fornecedores de "bens biológicos" em um "mercado humano" 30 .

\footnotetext{
${ }^{27}$ Id. Ibid., p. 140.

${ }^{28}$ Id. Ibid., p. 104.

${ }^{29}$ Id. Ibid. p. 554.

${ }^{30}$ Ver BERLINGUER, Giovanni; GARRAFA, Volnei. O mercado humano. 2. ed. Brasília: Ed. da UnB, 2001. p. 150 e ss.
} 
Ocorre que também o artigo $6^{\circ} \mathrm{e}$, com mais densidade normativa, o artigo $196 \mathrm{da} \mathrm{CF} / 88$ buscam concretizar a dignidade da pessoa humana por meio da garantia de condições mínimas para uma vida saudável ${ }^{31}$.

Desse modo, vê-se que a solução quanto a esse ponto particular parece não vir precisamente da ponderação sobre qual norma há de prevalecer no caso examinado, mas, antes, de qual interpretação melhor atende ao comando constitucional que dá fundamento às disposições em conflito.

Feitos os esclarecimentos, passa-se à proposta de solução.

Visto que a vedação do comércio de órgãos, tecidos e substâncias humanas trazida pelo parágrafo $4^{\circ}$ do artigo 199 da $\mathrm{CF} / 88$ é regra de direito fundamental destinada a promover o princípio da dignidade da pessoa humana, sua aplicação em determinado caso concreto não poderá significar violação deste mesmo princípio.

Como já mencionado, produtos biotecnológicos são elaborados com o uso de partes (ainda que por vezes microscópicas, como células modificadas por meio de manipulação genética) do corpo humano. São, pois, por definição, produtos derivados de substâncias humanas.

Ora, a oferta de soluções terapêuticas para a promoção e manutenção da saúde de todos é, como estipulado pelo artigo 196 do texto constitucional, um dever do Estado, a ser executado mediante a adoção de políticas sociais e econômicas que tenham por fim garantir acesso universal a ações e serviços capazes de incrementar a saúde individual e coletiva.

Nesse passo, infere-se que compreender a regra do parágrafo $4^{\circ}$ do artigo 199 como vedação ao comércio de produtos biotecnológicos somente se mostrará compatível com todo o texto constitucional se demonstrada sua proporcionalidade em face da tese contrária, isto é, a do reconhecimento da possibilidade do comércio de medicamentos baseados em biotecnologia - entendida esta última hipótese como meio de atender ao disposto no artigo $196 \mathrm{da} \mathrm{CF} / 88$.

Isso porque, como bem ressaltado em explicação de voto na Arguição de Descumprimento de Preceito Fundamental 54/DF julgada pelo STF, o processo de ponderação se dá, em última análise, entre razões de decidir fundamentadas em normas constitucionais diversas, mas potencialmente aplicáveis ao caso concreto. Trata-se, pois, de mecanismo para selecionar, dentre as escolhas jurídicas possíveis, aquela que, no caso concreto, reúne maior peso argumentativo com fundamento no texto constitucional.

\footnotetext{
${ }^{31}$ Ver BRASIL. SUPREMO TRIBUNAL FEDERAL. Recurso Extraordinário com Agravo 639337 AgR/SP. Disponível em: <http://www.stf.jus.br/portal/processo/verProcessoAndamento.asp?incidente=4063691>. Acesso em: 29 jan. 2016.
} 
Eis, por oportuno, trecho do voto citado:

Mais uma vez, a ponderação é de razões para decidir, e não propriamente de valores. Uma ponderação de valores só pode levar a um autoritarismo, pois não se pode justificar que um princípio seja mais importante do que o outro, pena de se tornar vulnerável a proteção da pluralidade, porque, como já demostrado, uma sociedade democrática e plural não conhece hierarquia de valores. A estipulação do valor mais "pesado" por uma corte constitucional não poderia se basear nos critérios determinados pelo próprio Direito tais como aceitos por todos aqueles que estão a ele sujeitos. Colocar na balança valores que têm o mesmo peso para dizer que um é mais valioso que o outro, mesmo que apenas para o caso, é criar uma ordem concreta de valores por um ato de autoridade. Portanto, a ponderação só pode ser das razões que aumentam a aceitação da racionalidade (e não da autoridade) da decisão ${ }^{32}$.

O teste da proporcionalidade passa, por seu turno, por três etapas sucessivas e prejudiciais, em que são verificadas a adequação, a necessidade e a proporcionalidade em sentido estrito da interpretação pretendida da norma de direito fundamental ${ }^{33}$. Dado o caráter prejudicial das fases do teste, a reprovação em qualquer das etapas impede o prosseguimento da análise e implica o reconhecimento da desproporcionalidade (e, por conseguinte, da inconstitucionalidade) da interpretação ou medida examinada.

A primeira das etapas é a da adequação. Em síntese, é adequada a medida capaz de fomentar o fim a que se destina ${ }^{34}$. No caso concreto, a interpretação do parágrafo $4^{\circ}$ do artigo 199 como veto ao comércio de produtos biotecnológicos foi inicialmente defendida como forma de promover a dignidade da pessoa humana, na medida em que impediria a venda de órgãos, tecidos e substâncias humanas por indivíduos premidos pela necessidade.

Em um primeiro momento, reconhece-se que o conceito de dignidade da pessoa humana é polissêmico e retórico, dependendo em grande medida da ideologia adotada por seu propositor ${ }^{35}$. Nada obstante, a ideia básica de que o ser humano não pode ser instrumento para o alcance de algum fim estabelecido por vontade alheia parece contar com ampla aceitação doutrinária ${ }^{36}$ e jurisprudencial ${ }^{37}$ no país.

\footnotetext{
${ }^{32}$ BRASIL. SUPREMO TRIBUNAL FEDERAL. ADPF 54/DF, cit.

${ }^{33}$ Ver SILVA, Virgílio Afonso da. O proporcional e o razoável. Revista dos Tribunais, São Paulo, v. 91, n. 798, p. 34, abr. 2002.

${ }^{34}$ Id. Ibid., p. 36.

${ }^{35}$ ADEODATO, João Maurício. Tolerância e conceito de dignidade da pessoa humana no positivismo ético. In: COUTINHO, Aldacy; GRAU, Eros et al. (Orgs.). Liber Amicorum. Homenagem ao Prof. Doutor António José Avelãs Nunes. Coimbra: Coimbra Ed., 2009. p. 512.

${ }^{36}$ Ver SARLET, Ingo Wolfgang. op. cit., p. 62.

${ }^{37}$ Ver voto do ministro relator da ADPF 54/DF. BRASIL. SUPREMO TRIBUNAL FEDERAL. ADPF 54/DF, cit.
} 
De igual sorte, ainda que reconhecendo as dificuldades em se precisar um conceito de dignidade também na estrutura constitucional alemã, Böckenförde atenta para alguns elementos tidos como incontroversos à noção discutida:

Este núcleo de dignidade abrange a posição e o reconhecimento do homem como sujeito individualizado; a liberdade de autodeterminação e desenvolvimento; a proibição de instrumentalização do homem, como se fosse uma coisa meramente disponível e desfrutável, e formulado de forma positiva, o direito de ter direitos, que devem ser considerados e protegidos ${ }^{38}$.

Sob esse aspecto, tem-se que a interpretação que sustenta o veto ao comércio de produtos biotecnológicos mostra-se potencialmente capaz de fomentar o aspecto da dignidade, uma vez que suprime a demanda por substâncias de origem humana necessárias para a fabricação dos produtos. Trata-se, pois, de medida que satisfaz a primeira das etapas do teste da proporcionalidade.

A segunda etapa do teste diz respeito à necessidade da medida. Entende-se necessária uma medida apenas quando evidenciada a ausência de outra igualmente adequada, porém menos restritiva para atingir o mesmo fim proposto.

No dizer de Virgílio Afonso da Silva:

Um ato estatal que limita um direito fundamental é somente necessário caso a realização do objetivo perseguido não possa ser promovida, com a mesma intensidade, por meio de outro ato que limite, em menor medida, o direito fundamental atingido ${ }^{39}$.

No presente momento, resgatam-se duas premissas expostas no texto, por questões de oportunidade e clareza. Primeiro, a interpretação do parágrafo $4^{\circ}$ do artigo 199 como vedação também a produtos biotecnológicos ${ }^{40}$ se pôs como exigência do princípio da dignidade humana, potencialmente violado pela venda de tecidos por hipossuficientes. Segundo, o mesmo princípio da dignidade, conjugado ao direito fundamental à saúde, pode ser interpretado como mandado de otimização do acesso a soluções terapêuticas para males que afligem indivíduos, males estes potencialmente curáveis ou ao menos mitigáveis por meio do uso de biotecnologia.

Assim posta a questão, tem-se que a interpretação restritiva do parágrafo $4^{\circ}$ do artigo 199 não satisfaz o teste da necessidade.

\footnotetext{
${ }^{38}$ BÖCKENFÖRDE, Enest-Wolfgang. Dignidade humana como príncipio normativo: os direitos fundamentais no debate bioético. In: SARLET, Ingo Wolfgang e LEITE, George Salomão (Orgs.). Direitos fundamentais e biotecnologia. São Paulo: Ed. Método, 2008. p. 66.

${ }^{39}$ SILVA, Virgílio Afonso da. op. cit., p. 38.

${ }^{40}$ Isto é: vedação não apenas ao comércio de "órgãos, tecidos e substâncias humanas", mas também de produtos destes derivados.
} 
De fato, a proteção de indivíduos hipossuficientes porventura seduzidos a mercadejar seu corpo pode ser concretizada por meio menos gravoso para o direito fundamental à saúde previsto nos artigos $6^{\circ}$ e 196 do texto constitucional.

Por certo, proibir apenas a captação remunerada de órgãos, tecidos e substâncias humanas usadas para a pesquisa e desenvolvimento de produtos biotecnológicos, mas não o comércio destes últimos, parece atingir satisfatoriamente o fim específico da proteção da dignidade da pessoa humana ditado pelo parágrafo $4^{\circ}$ do artigo 199 , sem, contudo, excluir a oferta de soluções terapêuticas inovadoras para efetivar o direito fundamental à saúde trazido pelos artigos $6^{\circ}$ e $196 \mathrm{da} \mathrm{CF} / 88$.

Nesse sentido, se a finalidade buscada pela vedação ao comércio de substâncias de origem humana do parágrafo $4^{\circ}$ do artigo 199 é a garantia da dignidade da pessoa humana contra um processo de "coisificação", é suficiente que a etapa da coleta do material biológico seja feita necessariamente de modo gracioso, como, aliás, já ocorre na seara infraconstitucional ${ }^{41}$.

Desse modo, identificada alternativa que promova a finalidade da norma de direito fundamental em questão (dignidade da pessoa humana) em intensidade similar, porém sem o sacrifício do uso de produtos biotecnológicos para a efetivação do direito fundamental à saúde, mister reconhecer que interpretar a regra do parágrafo $4^{\circ}$ do artigo 199 de forma "absolutista" ${ }^{2}$ mostra-se medida desnecessária e, portanto, desproporcional.

A proposta ora encaminhada traz, ademais, a vantagem de dirimir a questão no âmbito do marco dogmático adotado pelo STF. Ao apontar a desproporcionalidade da interpretação restritiva adotada por parte da doutrina e autoridade sanitária quanto ao comércio de produtos biotecnológicos (porque, como visto, a restrição é desnecessária), permite que o princípio da dignidade humana seja promovido sob outra perspectiva.

De fato, tal como já ressaltado, o caráter prestacional do direito à saúde revelado pelo artigo 196 do texto constitucional imbrica-se com a ideia de promoção estatal da dignidade da pessoa humana. Nesse sentido, o gozo de certas condições materiais, dentre as quais o acesso a prestações para garantir uma vida minimamente saudável, é decorrência do princípio veiculado pelo artigo $1^{\circ}$, inciso III, da $\mathrm{CF} / 88$, como ressaltado pelo ministro relator de precedente do STF, de que se extrai o trecho transcrito:

\footnotetext{
${ }^{41}$ Vejam-se os artigos $1^{\circ}$ e 15 da Lei n. 9.434/1997; o artigo $1^{\circ}$ da Lei n. 10.205/2001; e o artigo $5^{\circ}$, parágrafo $3^{\circ}$, da Lei n. 11.105/2005, todos vedando o comércio na captação de substâncias de origem humana.

${ }^{42}$ Expressão de BASTOS, Celso Ribeiro; MARTINS, Ives Gandra. op. cit., p. 183.
} 
A cláusula da reserva do possível - que não pode ser invocada, pelo Poder Público, com o propósito de fraudar, de frustrar e de inviabilizar a implementação de políticas públicas definidas na própria Constituição - encontra insuperável limitação na garantia constitucional do mínimo existencial, que representa, no contexto de nosso ordenamento positivo, emanação direta do postulado da essencial dignidade da pessoa humana. [...] A noção de 'mínimo existencial', que resulta, por implicitude, de determinados preceitos constitucionais (CF, art. $1^{\circ}$, III, e art. $3^{\circ}, \mathrm{III}$ ), compreende um complexo de prerrogativas cuja concretização revela-se capaz de garantir condições adequadas de existência digna, em ordem a assegurar, à pessoa, acesso efetivo ao direito geral de liberdade e, também, a prestações positivas originárias do Estado, viabilizadoras da plena fruição de direitos sociais básicos, tais como o direito à educação, o direito à proteção integral da criança e do adolescente, o direito à saúde, o direito à assistência social, o direito à moradia, o direito à alimentação e o direito à segurança. Declaração Universal dos Direitos da Pessoa Humana, de 1948 (Artigo XXV) ${ }^{43}$.

Assim, ao permitir que novas soluções terapêuticas sejam disponibilizadas à sociedade, sem, entretanto, permitir degradação da pessoa por meio do comércio de substâncias humanas, a interpretação proposta ao parágrafo $4^{\circ}$ do artigo 199 mostra-se mais compatível com a promoção sistêmica dos direitos fundamentais do que o entendimento mais restritivo propugnado por parte da doutrina e pela autoridade sanitária nacional.

\section{Considerações finais}

As aplicações terapêuticas da biotecnologia são ainda uma promessa ${ }^{44}$. Nada obstante, as possibilidades antevistas levaram à modificação do paradigma da indústria farmacêutica, de modo a reposicionar seu foco para o uso de substâncias de origem humana no tratamento de doenças.

A mudança do paradigma científico demanda, por sua vez, releitura do marco normativo, de modo a extrair de dispositivos antigos novas angulações normativas para conduzir a sociedade no enfrentamento dos desafios postos pelos novos conhecimentos técnicos.

$\mathrm{Na}$ ordem constitucional brasileira, que reconhece na dignidade da pessoa humana um dos fundamentos do Estado e se propõe a garantir a efetividade de

\footnotetext{
${ }^{43}$ ARE 639.337-AgR. BRASIL. SUPREMO TRIBUNAL FEDERAL. Recurso Extraordinário com Agravo 639337 AgR/SP, cit.

${ }^{44}$ LEITE, Marcelo. Promessas do genoma. São Paulo: Publifolha, 2000. p. 66.
} 
direitos fundamentais, mostra-se imprescindível o esforço para conciliar o progresso tecnológico com a criação de uma sociedade livre, justa e solidária, tal como projetado expressamente na própria Constituição.

Nesse sentido, interpretações constitucionais que impeçam o acesso a produtos biotecnológicos devem ser rechaçadas, por incompatíveis com o constitucionalismo humanista advindo com a promulgação da Constituição em 1988.

\section{Referências}

ADEODATO, João Maurício. Tolerância e conceito de dignidade da pessoa humana no positivismo ético. In: COUTINHO, Aldacy; GRAU, Eros et al. (Orgs.). Liber Amicorum. Homenagem ao Prof. Doutor António José Avelãs Nunes. Coimbra: Coimbra Ed., 2009. p. 509-523.

ALEXY, Robert. Teoria dos direitos fundamentais. 2. ed. São Paulo: Malheiros Ed., 2014.

BASTOS, Celso Ribeiro; MARTINS, Ives Gandra. Comentários à Constituição do Brasil. São Paulo: Saraiva, 2000. v. 8.

BERLINGUER, Giovanni; GARRAFA, Volnei. O mercado humano. 2. ed. Brasília: Ed. da UnB, 2001.

BÖCKENFÖRDE, Enest-Wolfgang. Dignidade humana como príncipio normativo: os direitos fundamentais no debate bioético. In: SARLET, Ingo Wolfgang e LEITE, George Salomão (Orgs.). Direitos fundamentais e biotecnologia. São Paulo: Ed. Método, 2008. p. 59-75.

COUTINHO, Aldacy; GRAU, Eros et al. (Orgs.). Liber Amicorum. Homenagem ao Prof. Doutor António José Avelãs Nunes. Coimbra: Coimbra Ed., 2009.

FERREIRA FILHO, Manoel Gonçalves. Comentários à Constituição brasileira de 1988. 2. ed. São Paulo: Saraiva, 1999.

HESSE, Konrad. Elementos de direito constitucional da República Federal da Alemanha. Porto Alegre: Sérgio Antônio Fabris, 1998.

LEITE, Marcelo. Promessas do genoma. São Paulo: Publifolha, 2000.

MARLAJOVICH, Maria. Biotecnologia. Rio de Janeiro: Axcel, 2004.

MENDES, Gilmar Ferreira; COELHO, Inocêncio Mártires; BRANCO, Paulo Gonet. Curso de direito constitucional. 2. ed. São Paulo: Saraiva, 2008.

MOSER, Antônio. Biotecnologia e bioética: para onde vamos? Petrópolis: Vozes, 2004.

REPÚBLICA FEDERAL DA ALEMANHA. Lei Fundamental da República Federal da Alemanha, de 23 de maio de 1949. Bonn, 1949. 
Comércio de produtos biotecnológicos no Brasil e o direito à saúde

SARLET, Ingo Wolfgang. Dignidade da pessoa humana e direitos fundamentais na Constituição Federal de1988. 9. ed. Porto Alegre: Livr. do Advogado, 2011.

; LEITE, George Salomão (Orgs.). Direitos fundamentais e biotecnologia. São Paulo: Ed. Método, 2008.

SILVA, José Afonso da. Curso de direito constitucional positivo. 17. ed. São Paulo: Malheiros Ed., 1999.

SILVA, Virgílio Afonso da. O proporcional e o razoável. Revista dos Tribunais, São Paulo, v. 91, n. 798 , p. 23-50, abr. 2002.

Victor V. Carneiro de Albuquerque - Mestrando em Direito pelo UniCEUB; especialista em Direito Regulatório pela Universidade de Brasília. Advocacia-Geral da União; Procurador Federal. Brasília/DF, Brasil. E-mail: victor.albuquerque@gmail.com. 